PREPARED IN COOPERATION WITH

THE MICHIGAN DEPARTMENT OF CONSERVATION

GEOLOGICAL SURVEY DIVISION

\title{
AEROMAGNETIC MAP OF THE SIDNAW QUADRANGLE . HOUGHTON AND BARAGA COUNTIES, MICHIGAN
}

\author{
GEOPHYSICAL INVESTIGATIONS \\ MAP GP-601
}

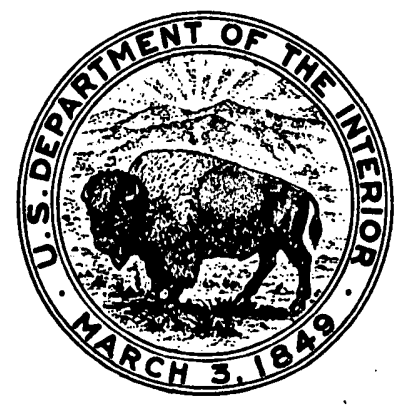

PUBLISHED BY THE U. S. GEOLOGICAL SURVEY WASHINGTON, D. C. 